\title{
ON THE ROLE OF LONG-CHAIN ALDEHYDES IN THE LIGHT REACTION IN PHOTOBACTERIUM PHOSPHOREUM ENZYME PREPARATIONS
}

\author{
WILLEMKE TERPSTRA \\ Biophysical Research Group, Physical Institute of the State University, Utrecht (The Netherlands) \\ (Received September 23rd, 1959)
}

\section{SUMMARY}

(I) Active luciferase-DPNH-oxidase preparations from Photobacterium phosphoreum generally contain some aldehyde-attacking enzyme, probably $\mathrm{ADH}$. Under the experimental conditions applied this enzyme appears to attack decanal, but not palmital.

(2) The presence of long-chain aldehydes in the enzyme preparations could be demonstrated. It was not possible to establish with certainty that the substance that is active in the light reaction catalyzed by enzyme preparations without added aldehyde is a long-chain aldehyde.

(3) There is no experimental evidence for the conversion of palmital in the light reaction.

(4) Extraction of enzyme preparations of $P h$. phosphoreum with iso-octane increases the light reaction; it seems probable that an inhibitor of luciferase is removed. Palmital, added to the enzyme preparations, is only slightly extracted by iso-octane.

(5) The extent of the light reaction in the enzyme preparations extracted with iso-octane depends on the sequence of addition of palmital, DPNH and FMN; the highest reaction is obtained if palmital is added first. The effect is influenced by aldehyde- and FMN concentrations; it is less conspicuous in non-extracted preparations.

(6) The experimental facts can be explained if it is assumed that palmital (or a long-chain aldehyde very similar to palmital) serves as a binding agent between the protein and FMNH. The possibility of a second, direct attachment of FMNH to the protein is discussed.

\section{INTRODUCTION}

In I953 STREHLER AND CORMIER ${ }^{\mathbf{l}}$ reported that kidney cortex extract could increase the light reaction in enzyme preparations of luminous bacteria. The active substance proved to be palmital ${ }^{2}$. STREHLER AND CORMIER ${ }^{1}$ found that heat-precipitable

Abbreviations: $\operatorname{DPN}(\mathrm{H})$, (reduced) diphosphopyridine-nucleotide; $\mathrm{FMN}(\mathrm{H})$, (reduced) flavin mononucleotide; $\mathrm{ADH}$, alcohol dehydrogenase. 
fractions obtained from Achromobacter fischeri are active in promoting the light reaction of preparations of luminous bacteria. It has not been demonstrated, however, that this activation is due to the presence of long-chain aldehydes in these fractions.

Besides palmital, other long-chain aldehydes ( 7 or more $\mathrm{C}$ atoms) were found to be active in this respect ${ }^{2}$; since it is difficult to obtain palmital, most experiments were done with decanal (C Io).

Cormier AND TotTER ${ }^{3}$ summarize the events that lead to light emission in bacteria as follows:

$$
\begin{gathered}
\text { DPNH }+ \text { FMN } \stackrel{\text { DPNH-oxidase }}{\rightarrow} \rightarrow \mathrm{FMNH}+\mathrm{DPN} \\
\mathrm{RCHO}+\mathrm{O}_{2}+\mathrm{FMNH} \stackrel{\text { inciferase-FMN }}{\longrightarrow} \mathrm{RCOOH}(?)+\mathrm{FMN}+\mathrm{H}_{\mathbf{2}} \mathrm{O}+\text { light }
\end{gathered}
$$

It will be shown in this paper that the conversion of the long-chain aldehyde cannot as yet be considered to be definitely proved.

The experiments described here were carried out in an attempt to throw some more light on the role of long-chain aldehydes in the light reaction. Further, an attempt was made to check the assumption that the active substance present in luminous bacteria is a long-chain aldehyde.

\section{MATERIAL AND METHODS}

Photobacterium phosphoreum was cultivated in a shaking apparatus at about $\mathrm{I} 7^{\circ}$ in a liquid medium containing I \% peptone (Difco "Bacto"), $3 \% \mathrm{NaCl}$ and $0.3 \%$ glycerol in tap water at $\mathrm{pH} 7 \cdot 3-7 \cdot 5$. The enzyme preparations were made following the method of MCELRoy et al. ${ }^{4}$. Except where otherwise stated, the $\mathrm{HCl}$ precipitate of the supernatant of lysed cells, dissolved in o.I $M$ phosphate buffer $\mathrm{pH} 7.0$, was used. No DPNH-oxidase was added. The light reaction was evoked by adding $0.5 \mathrm{mg}$ DPNH (dissolved in $0.5 \mathrm{ml}$ o.I $M$ phosphate buffer pH 7.0), $0.2 \mathrm{ml} \mathrm{FMN} \mathrm{solution} \mathrm{(0.00I} \mathrm{\% )}$ and $0.0 r-0.025 \mathrm{ml}$ palmital solution (a freshly made, mostly saturated solution in methanol, diluted as indicated in the experiments) to I ml enzyme preparation. In the experiments with decanal a saturated decanal solution in o.I $M$ phosphate buffer $\mathrm{pH} 7.0$ was used.

Palmital was prepared from the corresponding acid chloride according to Rosenmund ${ }^{5}$.

Extraction with iso-octane was performed at room temperature by shaking the enzyme preparation for $2 \mathrm{~min}$ with an equal volume of iso-octane; after centrifugation for Io min the two layers were separated.

The light reaction proceeded in a cuvette cooled with tap water (resulting in a temperature of the reaction mixture of about $\left.I 7^{\circ}\right)$. Two preparations could be measured alternately in one experiment. The light was measured in a quantum counter, operating with a liquid-air-cooled photo-multiplier ( $c f$. Smrт et al. $\left.{ }^{\mathbf{6}}\right)$. The individual estimations were accurate to within approximately Io \%.

DPNH-oxidase activity was determined by measuring spectrophotometrically the decrease of absorption at $340 \mathrm{~m} \mu$ in the same reaction mixture as was used for the light reaction.

$\mathrm{ADH}$ activity was measured in a similar way, using acetaldehyde as a substrate and omitting FMN. 


\section{EXPERIMENTS AND CONCLUSIONS}

\section{A. The conversion of decanal and palmital. The identity of the active factor in the light reaction}

In order to ensure a relatively durable light reaction of enzyme preparations, at least two enzymes should be present: DPNH-oxidase (for a constant production of FMNH from FMN) and luciferase (for the light reaction proper), (cf. TOTTER AND CORMIER $^{7}$ ). In thoroughly purified luciferase preparations DPNH-oxidase is absent. Therefore the best reaction is obtained with relatively impure enzyme preparations. We therefore used $\mathrm{HCl}$ precipitates of extracts of luminous bacteria. However, the presence of $\mathrm{ADH}$ (which catalyzes a reduction of aldehyde) in these preparations is a disadvantage. Even in purified but still active enzyme preparations (fractionated with $\left.\left(\mathrm{NH}_{4}\right)_{2} \mathrm{SO}_{4}\right)$ some $\mathrm{ADH}$ activity could be detected. Although ADH is most active towards short-chain aldehydes $\left(\mathrm{RACKER}^{8}\right)$, it also appears to use decanal as a substrate (TOTTER AND CORMIER ${ }^{7}$ ).

In our preparations, preincubation with decanal led to a decreased light reaction. This effect is much more pronounced if DPNH is present during the preincubation time (the light reaction being initiated with FMN afterwards). To a lesser extent this effect was observed in preparations purified by $\left(\mathrm{NH}_{4}\right)_{2} \mathrm{SO}_{4}$ fractionation; it is probably due to the presence of $\mathrm{ADH}$ in the preparations.

The preincubation effect was not observed if palmital was used instead of decanal (Table I). Evidently the palmital is not attacked in the presence of DPNH by enzyme systems other than that active in the light reaction.

TABLE I

THE INFLUENCE OF THE DURATION OF PRE-INCUBATION WITH PALMITAL AND DECANAL ON THE LIGHT REACTION

\begin{tabular}{|c|c|c|c|c|c|}
\hline \multirow{3}{*}{$\begin{array}{l}\text { Expt. } \\
\text { No. }\end{array}$} & \multirow{3}{*}{$\begin{array}{c}\text { Enzyme } \\
\text { preparation }\end{array}$} & \multicolumn{4}{|c|}{ Light reaction (counts/\%/ $\mathrm{min}$ ) } \\
\hline & & \multicolumn{2}{|c|}{$\begin{array}{c}\text { Incubation with } \\
\text { palmital }+D P N H\end{array}$} & \multicolumn{2}{|c|}{$\begin{array}{l}\text { Incubation with } \\
\text { decanal }+D P N H\end{array}$} \\
\hline & & $I \min$ & $I I \min$ & $I \min$ & II $\mathrm{min}$ \\
\hline I & $12-6$ & $23 I$ & 225 & 927 & 597 \\
\hline 2 & $29-5$ & 108 & 109 & I 79 & I 30 \\
\hline 3 & $12-6$ & 160 & I $5^{8}$ & $53^{8}$ & $3^{85}$ \\
\hline
\end{tabular}

Reaction mixture: I $\mathrm{ml}$ enzyme, $0.5 \mathrm{mg} \mathrm{DPNH}$ in $0.5 \mathrm{ml}$ phosphate buffer $\mathrm{pH} 7.0,0.2 \mathrm{ml} \mathrm{FMN}$ $0.001 \%$, 0.0 I $\mathrm{ml}$ palmital solution I:20, 0.I $\mathrm{ml}$ (Expts. I and 2) or $0.05 \mathrm{ml}$ (Expt. 3) decanal solution. Initiation of the reaction with FMN, measurement 4 min after the addition of FMN.

This finding may explain the difference of the decay curves of the light reactions when using either decanal or palmital (Fig. Ia). The decay of the "decanal curve" is probably due to the conversion of decanal, independent of the light reaction.

The curve of the light reaction without addition of a long-chain aldehyde resembles the curve of the reaction with palmital (Fig. Ib). If the unknown substance essential for the light reaction in the original enzyme preparation were an aldehyde, this resemblance might indicate that its chain length is of the order of that of palmital.

We tried to demonstrate chemically the presence of long-chain aldehydes in the enzyme preparations. A preparation of about I2 $\mathrm{g}$ of bacteria (wet weight) was 
extracted with methanol-chloroform, following the method of FoLCH ${ }^{9}$. In the extract, the long-chain aldehydes were determined according to WITTENBERG et al. ${ }^{10}$. The amount of aldehyde proved to be Io-20 times the amount that might be expected with regard to the light reaction. Probably the preparations contain plasmalogens (acetal phospholipids). It will be shown in section B that extraction of palmital from luciferase may give rise to complications. Therefore, these experiments do not prove that the long-chain aldehyde found in the preparations participates in the light reaction.

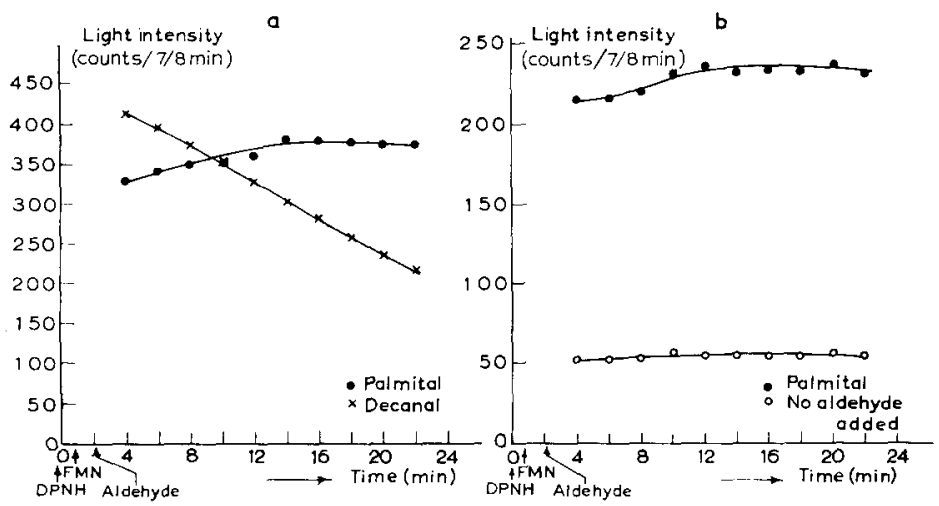

Fig. I. The light reaction with palmital, decanal and without added aldehyde.

Since, apparently, palmital is no substrate for bacterial ADH, it seemed worth while to consider the question of the conversion of aldehyde during the light reaction once more. MCELROY AND GREEN ${ }^{11}$ found that the light emitted by bacterial enzyme preparations is directly dependent upon aldehyde concentration. This they interpreted as indicating an utilization of aldehyde in the light reaction. However, it may be objected that the reaction velocity would also, to a certain degree, depend on aldehyde concentration if aldehyde were acting as a catalyst.

The subject has been recently dealt with by CORMIER AND TOTTER ${ }^{3}$, who estimated the quantum efficiency of decanal in the light reaction. However, their preparations were not highly purified, so some ADH may have been present. The decay in the light reaction, presented in Fig. 2 of their publication, may be due to the conversion of decanal by ADH. They tried to prove the absence of aldehyde-attacking enzymes other than luciferase by a preincubation experiment in which they obtained more light after incubation with decanal and DPNH for I5 min than after incubation with these substances plus FMN for the same length of time. The result of this experiment, however, may be explained by the fact that oxidation of DPNH by DPNH-oxidase proceeds much faster in the presence of added FMN (cf. ref. 7). In other words, preincubation with FMN diminishes the DPNH concentration. Thus, this experiment does not prove that FMN is required for the utilization of aldehyde in the light reaction.

When considering the question of the conversion of aldehyde during the light reaction, it was established first (spectrophotometrically) that the presence of palmital does not detectably influence the rate of DPNH oxidation in an enzyme preparation containing FMN. It seems probable that the presence of aldehyde only causes a small part of FMNH to be oxidized via the light reaction instead of via the autoxidation pathway. 
The light reaction, in the presence of excess DPNH and a limiting amount of palmital is constant for some time (Fig. Ia, b). The length of the horizontal part of the curve depends on DPNH supply. We examined whether the initial light reaction could be restored by addition of DPNH after a rather long reaction time $(54 \mathrm{~min})$. This proved to be possible in some experiments (Table II). Since some decrease of the enzyme activity (luciferase or DPNH-oxidase) may be expected during this relatively long incubation time, it does not seem surprising that not all experiments yielded this result. Therefore, we conclude that, as yet, there is no reason for assuming a conversion of long-chain aldehyde during its activity in the light reaction.

TABLE II

THE RESTORATION OF THE LIGHT REACTION WITH DPNH

\begin{tabular}{cccc}
\hline Expt. No. & \multicolumn{3}{c}{ Light reaction (counts $/ 7$ in min) } \\
\hline Initial & After 5o min & $\begin{array}{c}\text { After } 54 \text { min } \\
\text { and addition of } \\
\text { fresh DPNH }\end{array}$ \\
\hline 2 & 608 & 120 & 634 \\
3 & 282 & 79 & 259 \\
4 & 376 & 128 & 303 \\
5 & 236 & 36 & 254 \\
& 55 & 9 & 51
\end{tabular}

Reaction mixture: I $\mathrm{ml}$ enzyme preparation, $\mathrm{I} .2 \mathrm{mg} \mathrm{DPNH}$ in $0.5 \mathrm{ml}$ phosphate buffer pH 7.0 , $0.2 \mathrm{ml}$ FMN $0.001 \%$, $0.02 \mathrm{ml}$ palmital sol. I : 20. DPNH + FMN were added before palmital. After $54 \mathrm{~min}$ about $0.5 \mathrm{mg}$ DPNH was added. Measurement of the initial reaction at its highest rate (18 min after palmital addition), measurement of the restored reaction 4 min after DPNH addition. In Expt. 5 no palmital was added.

In the next experiments we always used palmital instead of decanal in order to avoid complications caused by a conversion of decanal independent of the light reaction.

\section{$B$. The infuence of iso-octane extraction of enzyme preparations on the light reaction}

When no aldehydes were added all enzyme preparations showed a weak light reaction in the presence of DPNH and FMN. It was supposed, therefore, that the preparations contained some aldehyde (see section A). STrEhler ANd Cormier ${ }^{1}$ found that a boiled extract of an acetonized bacterial preparation produces an increase in luminescence. Our boiled enzyme preparations, however, inhibited the light reaction if added to untreated preparations plus DPNH and FMN. We tried to extract the active substance by means of organic solvents. The evaporated extracts caused an inhibition of the light reaction. However, this did not prove the absence of long-chain aldehydes in the extracts since it appeared to be difficult to redissolve, after evaporation of the organic solvent, a small amount of palmital in buffer. We then tried to investigate whether the enzyme preparation had lost its active substance by the extraction. We therefore looked for a solvent that would not be likely to inactivate the enzyme preparation by protein denaturation, in order to be able to test the extracted preparation in the light reaction; iso-octane was used. Since the extraction of long-chain aldehyde, supposed to be present, was anticipated, it was expected that the extracted enzyme preparation would yield a decreased light reaction with DPNH and FMN. Contrary to expectation, however, the iso-octane-extracted enzyme 
system exhibited a clearly increased light reaction. Moreover, the relative increase of the light reaction in the presence of palmital is still higher (Table III).

TABLE III

THE INFLUENCE OF ISO-OCTANE EXTRACTION ON THE LIGHT REACTION

\begin{tabular}{|c|c|c|c|c|c|c|c|}
\hline \multirow{3}{*}{ Expt. No. } & \multirow{3}{*}{$\begin{array}{l}\text { Enzyme } \\
\text { preparation }\end{array}$} & \multicolumn{3}{|c|}{ No palmital auded } & \multicolumn{3}{|c|}{ Palmital addcd } \\
\hline & & \multicolumn{2}{|c|}{$\begin{array}{l}\text { Light reaction } \\
\text { (counts } \% \text { min) }\end{array}$} & \multirow{2}{*}{$\begin{array}{l}\text { Ratio veactions } \\
\text { exiracted/un-extracted } \\
\text { cnzyme }\end{array}$} & \multicolumn{2}{|c|}{$\begin{array}{l}\text { Light reaction } \\
(\text { counts/7/s min) }\end{array}$} & \multirow{2}{*}{$\begin{array}{c}\text { Ratio reactions } \\
\text { extracted/un-extracted } \\
\text { enzyme }\end{array}$} \\
\hline & & $\begin{array}{l}\text { Enzyme not } \\
\text { extracted }\end{array}$ & $\begin{array}{c}\text { Enzyme } \\
\text { extracted } \\
\text { with iso-octane }\end{array}$ & & $\begin{array}{c}\text { Enzyme not } \\
\text { extracted }\end{array}$ & $\begin{array}{l}\text { Enzyme } \\
\text { cxtracted } \\
\text { with iso-octane }\end{array}$ & \\
\hline I & $1 \rightarrow \mathrm{I} 2$ & I & 3 & 一 & 107 & J 84 & 1.7 \\
\hline 2 & $12-12$ & I 8 & 33 & 1.8 & $\log 8$ & 2519 & 2.3 \\
\hline 3 & $12-12$ & 20 & 94 & 4.7 & 972 & $795^{\circ}$ & 8.2 \\
\hline 4 & $12-12$ & I 4 & 25 & I. 8 & $\operatorname{Io62}$ & $375^{\circ}$ & $3 \cdot 5$ \\
\hline 5 & $I-12$ & 3 & 6 & 2.0 & I 23 & 498 & 4.0 \\
\hline 6 & $\mathrm{I} 2-\mathrm{I} 2$ & I 8 & 24 & $1 \cdot 3$ & 7 I 4 & $263^{2}$ & $3 \cdot 7$ \\
\hline 7 & $\mathrm{I}-\mathrm{I} 2$ & 7 & 14 & 2.0 & 208 & 509 & 2.4 \\
\hline & $12-12$ & & & & & & \\
\hline 8 & I 2- I & 90 & 193 & 2.1 & 2320 & 3860 & 1.7 \\
\hline 9 & $9-2$ & $4^{1}$ & 53 & I. 3 & 1055 & 1865 & I. 8 \\
\hline 10 & $9-2$ & 33 & 172 & $5 \cdot 2$ & 1254 & 6700 & $5 \cdot 3$ \\
\hline & $30-I$ & & & & & & \\
\hline I I & $30-I$ & 39 & $7 \mathrm{I}$ & I. 8 & 257 & 388 & I. 5 \\
\hline 12 & $30-1$ & 40 & I I I & 2.8 & 257 & 587 & 2.3 \\
\hline 13 & $16-2$ & $4^{\circ}$ & 73 & I. 8 & $34^{1}$ & 816 & 2.4 \\
\hline 14 & $3-4$ & io & I 3 & $1 \cdot 3$ & 44 & I 24 & 2.8 \\
\hline I 5 & $3-4$ & 8 & I 2 & 1.5 & 77 & $33^{\circ}$ & $4 \cdot 3$ \\
\hline
\end{tabular}

Reaction mixtures: I ml enzyme preparation, $0.5 \mathrm{mg}$ DPNH in $0.5 \mathrm{ml}$ phosphate buffer $\mathrm{pH} 7.0$, $0.2 \mathrm{ml} \mathrm{FMN} 0.00 \mathrm{r} \%$, palmital solution $0.025 \mathrm{ml}$ i : Io (Expts. I-6), o.01 ml I : Io (Expts. 7, 8, 9 , IO, I 5), 0.OI $\mathrm{ml} \mathrm{I}: 40$ (Expts. I I, I2, 13), $0.025 \mathrm{ml} \mathrm{I} \mathrm{:40} \mathrm{(Expt.} \mathrm{I} \mathrm{4).}$

Iso-octane extraction of mitochondrial particles is known to cause a decrease of the cytochrome $c$-reductase activity ${ }^{12}$, perhaps by removing some essential component in the electron-transfer system ${ }^{13}$. The effect of iso-octane extraction in our preparations might be due to the removal of such a component from a cytochrome $c$-reductase system competing with luciferase for $\mathrm{FMNH}$ :

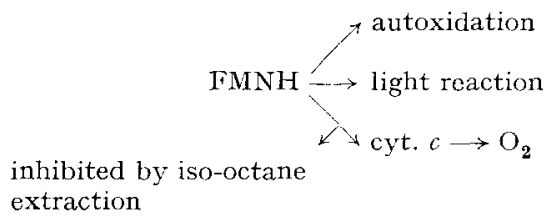

TOTTER AND CORMIER ${ }^{7}$ demonstrated that oxidized cytochrome $c$ is an inhibitor of the light reaction. They ascribed this inhibition to competition between cytochrome $c$ and luciferase for the $\mathbf{H}$ of FMNH. Assuming the presence of a cytochrome $c$-reductase system in our preparations, cytochrome $c$ should cause no, or at least a decreased, inhibition of the light reaction in a preparation, extracted with iso-octane, if an essential component of the cytochrome $c$-reductase system had been removed. This proved not to be the case: addition of cytochrome $c$ (about $0.9 \mathrm{mg} / 2 \mathrm{ml}$ reaction mixture) caused an inhibition of the light reaction of $42 \%$ in an unextracted preparation and of $44 \%$ in a preparation extracted with iso-octane. 
No absorption peak in the region between 4000 and $4500 \AA$ could be detected in the concentrated iso-octane fraction, indicating the absence of measurable amounts of cytochrome components.

Furthermore, it was established that iso-octane extraction does not influence the rate of DPNH oxidation in the presence of FMN. The presence of palmital is without effect in this respect.

It was tested whether the effect of iso-octane extraction could be ascribed to some physical cause ${ }^{14-16}$. However, both with and without palmital, addition of some iso-octane to an enzyme preparation did not influence the light reaction.

Residues of evaporated iso-octane extracts appeared to inhibit the light reaction of enzyme preparations containing added palmital (Table IV). This result may indicate that iso-octane extracts an inhibitor from the enzyme preparations. This inhibitor does not influence DPNH oxidation.

TABLE IV

THE INFLUENCE OF EVAPORATED ISO-OCTANE EXTRACTS FROM ENZYME PREPARATIONS ON THE LIGHT REACTION OF NON-EXTRACTED ENZYME

\begin{tabular}{|c|c|c|c|c|c|}
\hline \multirow{3}{*}{$\begin{array}{l}\text { Expt. } \\
\text { No. }\end{array}$} & \multirow{3}{*}{$\begin{array}{c}\text { Enzyme } \\
\text { preparation }\end{array}$} & \multicolumn{4}{|c|}{ Light reaction (counts/7/s min) } \\
\hline & & \multicolumn{2}{|c|}{ No palmital added } & \multicolumn{2}{|c|}{ Palmital added } \\
\hline & & $\begin{array}{l}\text { No iso-actane } \\
\text { extract }\end{array}$ & $\begin{array}{l}\text { Iso-octane } \\
\text { extract }\end{array}$ & $\begin{array}{l}\text { No iso-octane } \\
\text { extract }\end{array}$ & $\begin{array}{c}\text { Iso-octane } \\
\text { extract }\end{array}$ \\
\hline I & $I--I 2$ & I & I & 107 & $5^{8}$ \\
\hline 2 & I $2-\mathrm{I} 2$ & I 8 & I 8 & 1098 & 518 \\
\hline 3 & $12-12$ & $17^{\star}$ & 17 & I $884^{\star}$ & 664 \\
\hline 4 & $I-I 2$ & $3^{\star}$ & 3 & $91^{*}$ & 54 \\
\hline
\end{tabular}

* With iso-octane extract from buffer.

Reaction mixtures : iso-octane extract of $5 \mathrm{ml}$ enzyme preparation taken up in $0.025 \mathrm{~m} 1 \mathrm{methanol}$ and $0.25 \mathrm{ml}$ phosphate buffer $\mathrm{pH} 7.0$, $1 \mathrm{ml}$ enzyme preparation, $0.5 \mathrm{mg} \mathrm{DPNH}$ in $0.25 \mathrm{ml} \mathrm{buffer}$, $0.2 \mathrm{ml}$ FMN $0.001 \%$, $0.025 \mathrm{ml}$ palmital solution I : Io.

The question arose why iso-octane apparently does not, apart from this inhibitor, extract the long-chain aldehyde supposed to be present in the enzyme preparations. It appeared that iso-octane extracts only a part of the palmital added to an enzyme preparation, while extraction from buffer is much more complete (Table V). These results indicate that added palmital is adsorbed or bound to the enzyme preparation and thus prevented from being extracted. The same conclusion was drawn from earlier dialysis experiments, using decanal.

\section{The infuence of the sequence in which palmital, DPNH and FMN are added}

In the earlier experiments carried out in order to determine the extractability of added palmital from enzyme preparations we often found that if a certain amount of palmital was added to an enzyme preparation prior to iso-octane extraction and the same amount was added to a similar preparation after iso-octane extraction (the control), more palmital (as estimated by means of the light reaction) seemed to be present afterwards in the first preparation than in the second one. This effect appeared to occur if, in the control, DPNH + FMN were added before the addition of palmital. We therefore investigated the influence of the sequence in which palmital, 


\section{TABLE V}

THE EXTRACTABILITY OF PALMITAL WITH ISO-OCTANE FROM ENZYME PREPARATIONS AND FROM BUFFER

\begin{tabular}{|c|c|c|c|}
\hline \multirow[b]{2}{*}{ Expt. No. } & \multirow[b]{2}{*}{$\begin{array}{l}\text { Palmital added } \\
\text { (ml/ml enzyme) }\end{array}$} & \multicolumn{2}{|c|}{ Palmital $(\%)$ extracted from } \\
\hline & & $\begin{array}{c}\text { Enzyme } \\
\text { preparation* }\end{array}$ & $\begin{array}{c}\text { Phosphate } \\
\text { buffer } p H 7.0^{\star *}\end{array}$ \\
\hline Ia & $0.008(\mathbf{I} ; \mathrm{IO})$ & 4 & \\
\hline I b & 0.008 & 13 & \\
\hline IC & 0.008 & 33 & \\
\hline $2 a$ & 0.008 & 38 & \\
\hline $2 \mathrm{~b}$ & 0.008 & 6 & \\
\hline $2 \mathrm{C}$ & 0.008 & $\mathbf{O}$ & \\
\hline 3 & 0.025 & & 74 \\
\hline $4 a$ & $0.01 \quad(I: 40)$ & 33 & \\
\hline $4 \mathrm{~b}$ & $0.01 \quad(I: 40)$ & 24 & \\
\hline 5 & $0.008(1: 10)$ & & IOO \\
\hline 6 & $0.008(\mathrm{I}: \mathbf{I} 0)$ & & 90 \\
\hline $7 a$ & 0.025 & $26^{\star \star \star}$ & \\
\hline $7 \mathrm{~b}$ & 0.025 & & $77^{\star \star \star}$ \\
\hline
\end{tabular}

* The light reaction with DPNH + FMN of (enzyme + palmital) extracted with iso-octane, compared with that of (enzyme extracted with iso-octane) + palmital.

In all controls DPNH + FMN were added after the palmital.

$\star \star$ The light reaction of enzyme + DPNH + FMN $+\{$ (palmital + buffer $)$ extracted with iso-octaned\}, compared with that of enzyme + DPNH + FMN + palmital + (buffer extracted with iso-octane).

${ }_{\star \star \star}$ Chemical estimation of aldehyde in the iso-octane fraction with $p$-nitrophenylhydrazine after Wittenberg et al. ${ }^{10}$.

TABLE VI

THE INFLUENCE OF THE SEQUENCE OF ADDITION OF PALMITAL AND DPNH + FMN ON THE LIGHT REACTION

\begin{tabular}{|c|c|c|c|c|c|c|}
\hline \multirow{2}{*}{ Expt. No. } & \multirow{2}{*}{$\begin{array}{c}\text { Enzyme } \\
\text { preparation }\end{array}$} & \multirow{2}{*}{$\begin{array}{l}\text { Sequence of addition } \\
\text { of palmital (P) and } \\
D P N H+F M N(D F)\end{array}$} & \multicolumn{2}{|c|}{ Light reaction (counts/\% $/ \mathrm{min}$ ) in } & \multicolumn{2}{|c|}{$\begin{array}{c}\text { Decrease of the light reaction (in \%) } \\
\text { on preincubation with } \\
\text { DPNH +FMN }\end{array}$} \\
\hline & & & $\begin{array}{l}\text { Unextracted } \\
\text { enzyme }\end{array}$ & $\begin{array}{c}\text { Enzyme } \\
\text { extracted } \\
\text { with iso-octane }\end{array}$ & $\begin{array}{l}\text { Unextracted } \\
\text { enzyme }\end{array}$ & $\begin{array}{c}\text { Enzyme } \\
\text { extracted } \\
\text { with iso-octane }\end{array}$ \\
\hline \multirow[t]{2}{*}{ I } & $30-I$ & $\mathrm{P}-\mathrm{DF}$ & 304 & 984 & 15 & 40 \\
\hline & & DF-P & 257 & 586 & & \\
\hline \multirow[t]{2}{*}{2} & I 6-2 & $\mathrm{P}-\mathrm{DF}$ & $35^{\mathrm{I}}$ & 1185 & 3 & $3^{I}$ \\
\hline & & $\mathrm{DF}-\mathrm{P}$ & 342 & 816 & & \\
\hline \multirow[t]{2}{*}{3} & $3-4$ & P.DF & 205 & $78 \mathrm{I}$ & 6 & 37 \\
\hline & & $\mathrm{DF}-\mathrm{P}$ & 193 & $49 \mathrm{I}$ & & \\
\hline \multirow[t]{2}{*}{4} & $4-3$ & $\mathrm{P}-\mathrm{DF}$ & 127 & 498 & 27 & 43 \\
\hline & & $D F-P$ & 93 & 286 & & \\
\hline
\end{tabular}

Reaction mixtures: $1 \mathrm{ml}$ enzyme preparation, $0.5 \mathrm{ml} \mathrm{DPNH}$ in $0.5 \mathrm{ml}$ phosphate buffer pH 7.0 , $0.2 \mathrm{ml}$ FMN $0.001 \%$, $0.01 \mathrm{ml}$ palmital sol. ( $1: 20$ or I :40). In every set of experiments the time during which DPNH + FMN were in contact with the enzyme was the same.

DPNH and FMN were added to the iso-octane-extracted preparation. There appeared to be a higher light production if palmital was added before DPNH and FMN, as compared with the light production in a preparation to which palmital was added after DPNH + FMN. The difference, although decreasing with time, was still clear 


\section{TABLE VII}

THE INFLUENCE OF PREINCUBATION WITH DPNH + FMN, DPNH AND FMN ON THE LIGHT REACTION OF ENZYME PREPARATIONS EXTRACTED WITH ISO-OCTANE

\begin{tabular}{|c|c|c|c|c|}
\hline \multirow[b]{2}{*}{ Expt. No. } & \multirow[b]{2}{*}{ Enzyme preparation } & \multicolumn{3}{|c|}{$\begin{array}{l}\text { Decrease of the light reaction (\%) of iso-octane- } \\
\text { extracted enzyme upon preincwbation with }\end{array}$} \\
\hline & & $\begin{array}{c}D P N H+F M N \\
(P-D-F \\
\text { verstus } \\
D-F-P)\end{array}$ & $\begin{array}{c}F M N \\
(P-F-D \\
\text { versus } \\
F-P-D)\end{array}$ & $\begin{array}{c}D P N H \\
(P-D-F \\
\text { versus } \\
D-P-F)\end{array}$ \\
\hline I & $24-4$ & 37 & 8 & - \\
\hline 2 & $24-4$ & 32 & I 8 & 20 \\
\hline 3 & $9-3$ & 37 & I 6 & I9 \\
\hline
\end{tabular}

Reaction mixtures as described for Table VI. Symbols in parentheses indicate sequence of addition of the reactants. P: palmital, $D: D P N H, F: F M N$. In every set of experiments the time during which DPNH + FMN, DPNH and FMN were in contact with the enzyme was the same.

\section{TABLE VIII}

INFLUENCE OF FMN CONCENTRATION UPON THE DECREASE OF THE LIGHT REACTION OF ENZYME PREPARATIONS EXTRACTED WITH ISO-OCTANE ON PREINCUBATION WITH DPNH + FMN

\begin{tabular}{|c|c|c|c|c|c|}
\hline \multirow{2}{*}{ Expt. No. } & \multirow{2}{*}{$\begin{array}{c}\text { Enzyme } \\
\text { preparation }\end{array}$} & \multirow{2}{*}{$\begin{array}{c}\text { Concentration } \\
F M N \text { added } \\
(\%)\end{array}$} & \multicolumn{2}{|c|}{$\begin{array}{l}\text { Light reaction } \\
(\text { counts } / \% / \mathrm{min})\end{array}$} & \multirow{2}{*}{$\begin{array}{c}\text { Decrease } \\
(\%)\end{array}$} \\
\hline & & & $P+D F$ & $D F+P$ & \\
\hline \multirow[t]{3}{*}{ I } & $9-3$ & $0.0 \mathrm{r}$ & 226 & $8 \mathrm{I}$ & 64 \\
\hline & & $0.00 \mathrm{I}$ & 565 & 418 & 26 \\
\hline & & $0.000 I$ & I 27 & I 2 I & -5 \\
\hline \multirow[t]{3}{*}{2} & I $2-6$ & $0.0 \mathrm{I}$ & 492 & 298 & $4^{\circ}$ \\
\hline & & 0.001 & I 320 & 865 & 35 \\
\hline & & 0.0001 & 310 & 264 & 15 \\
\hline
\end{tabular}

Reaction mixture as described for Table VI. P: Palmital. DF: DPNH + FMN. Sequence of symbols indicates sequence of addition of the reactants.

\section{TABLE IX}

INFLUENCE OF PALMITAL CONCENTRATION UPON THE DECREASE OF THE LIGHT REACTION IN ENZYME PREPARATIONS EXTRACTED WITH ISO-OCTANE ON PREINCUBATION WITH DPNH + FMN

\begin{tabular}{|c|c|c|c|c|c|}
\hline \multirow{2}{*}{$\begin{array}{l}\text { Expt. } \\
\text { No. }\end{array}$} & \multirow{2}{*}{$\underset{\text { preparation }}{\text { Enzyme }}$} & \multirow{2}{*}{$\begin{array}{l}\text { Concentration } \\
\text { palmital added } \\
(\mathrm{ml})\end{array}$} & \multicolumn{2}{|c|}{$\begin{array}{l}\text { Light reaction } \\
\text { (counts } / 7 / \mathrm{s} \text { min) }\end{array}$} & \multirow{2}{*}{$\begin{array}{c}\text { Decrease } \\
(\%)\end{array}$} \\
\hline & & & $P+\overline{D F}$ & $\overline{D F}+P$ & \\
\hline \multirow[t]{4}{*}{ I } & $29-5$ & 0.02 & $2 \mathrm{II}_{4}$ & 1924 & 9 \\
\hline & & $0.02(1: 5)$ & 353 & 315 & II \\
\hline & & $0.02(1: 20)$ & 108 & 63 & 42 \\
\hline & & $0.02(\mathrm{I}: 80)$ & 34 & I 8 & 47 \\
\hline \multirow[t]{4}{*}{2} & I $2-6$ & 0.02 & I $58 \mathrm{I}$ & 1486 & 6 \\
\hline & & $0.02(1: 5)$ & 602 & 446 & 26 \\
\hline & & $0.02(1: 20)$ & 272 & 173 & 36 \\
\hline & & $0.02(\mathrm{I}: 80)$ & 102 & 63 & $3^{8}$ \\
\hline
\end{tabular}

Reaction mixture as described for Table VI. P: Palmital, DF: DPNH + FMN. Sequence of symbols indicates sequence of addition of the reactants. The value of the light reaction without added palmital has been subtracted. 
after I5-20 minutes. The effect was likewise present in non-extracted preparations, though to a much smaller extent (Table VI). The time during which DPNH + FMN were in contact with the enzyme (varying from $7 \mathrm{sec}$ to ro min) did not influence the result. Preincubation with either DPNH or FMN caused a similar effect. However, the difference was smaller than after preincubation with DPNH + FMN (Table VII).

In former experiments ${ }^{17}$ we never observed this influence of the sequence of addition of the various components to $P h$. phosphoreum preparations. Rather was the reverse effect sometimes observed ( $c f$. Fig. I in ref. ${ }^{17}$ ). This may now be explained by the facts that: (I) the effect is most clear in preparations extracted with iso-octane, (2) when using decanal, as was done in our previous experiments, the effect is counteracted by the conversion of decanal, independent of the light reaction.

In order to obtain more insight into the cause of the phenomenon described above we studied the influence of the concentration of FMN and palmital. The difference (in percentage) between the light reactions produced by adding first palmital as compared with that obtained by adding first DPNH + FMN appeared to increase with increasing amounts of FMN, while a decrease was observed with increasing palmital concentrations (Tables VIII and IX).

\section{DISCUSSION}

Before trying to suggest an explanation for the phenomena described $B$, the experimental results may be briefly summarized as follows:

(I) Iso-octane extraction of enzyme preparations increases the light reaction, probably by removal of an inhibitor. It has no detectable influence on the DPNHoxidase activity. As a rule the iso-octane effect is more pronounced when palmital is added than when it is not.

(2) In iso-octane-extracted enzyme preparations the light reaction depends on the sequence in which palmital and DPNH + FMN are added. If palmital is added first the light reaction is for a considerable period higher than if palmital is added last. This effect is observed to a lesser extent in unextracted enzyme preparations.

(3) Palmital added to an enzyme preparation is only slightly removed by isooctane extraction.

(4) There is no evidence for a chemical change of aldehyde in the light reaction.

On the basis of previous experiments we developed a scheme for the luciferase molecule in which two different sites were present, one for binding $\operatorname{FMN}(\mathbf{H})$ and one for binding long-chain aldehydes. The site of FMNH might be occupied by aldehyde ${ }^{17}$. This scheme, however, fails to explain all the experimental facts mentioned above, especially the long-lasting "addition sequence effect" mentioned under (2). In the literature we found one instance of an effect comparable with that in question: in testing the influence of the order of addition of the components on the reconstruction of carboxylase activity, GREEN et al. ${ }^{18}$ observed that the greatest activity was found if magnesium was added to the protein prior to diphospho-thiamine. According to LEHNINGER $^{19}$ this suggests that $\mathrm{Mg}^{++}$serves as the binding agent between protein and diphospho-thiamine.

If we apply the suggestion of LEHNINGER to our enzyme system, i.e. if we consider the long-chain aldehyde as the binding group between the enzyme and $F M N(H)$, the 


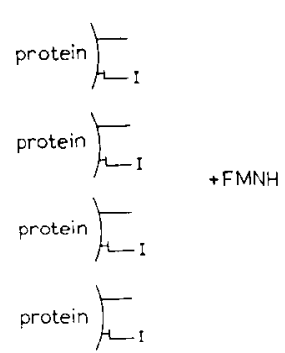

Unextracted enzyme molecules.

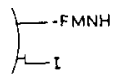

$r_{L-I}^{-F M N H}$<smiles>CC(C)C(C)C(N)I</smiles><smiles>CC(C)C(C)C#N</smiles>

FMNH takes its sites at the enzyme.

It cannot block the sites screened by $\mathbf{I}$.

+ Poimital $(m)$

$-\sim_{I}$

$F-N$ N<smiles>CC(C)CC(C)C(=N)O</smiles>

$\underset{-N}{-}{ }_{M}^{N}$ (light)

Palmital decreases the affinity of I to the enzyme, the light reaction can take place at the uninhibited enzyme.

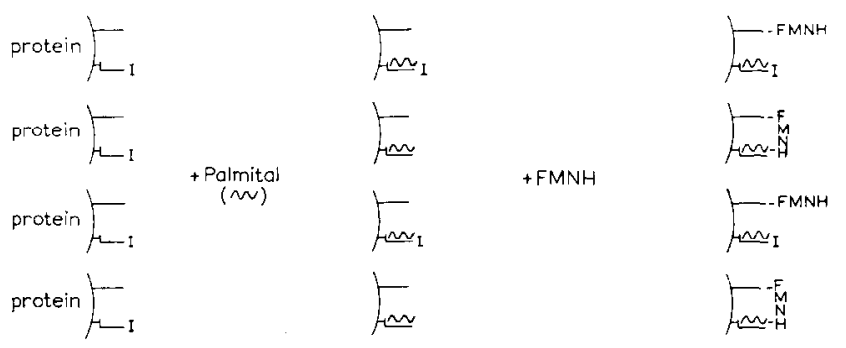

Unextracted enzyme Palmital occupies the molecules. enzyme, the affinity of I to the enzyme is decreased.

FMNH occupies its sites, the light reaction occurs at the uninhibited enzyme.

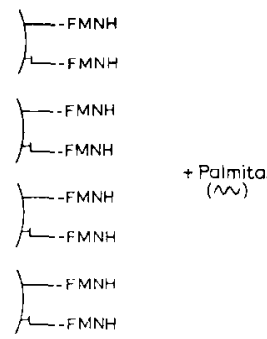

FMNH blocks the pal-

Iso-octane extracted mital sites.<smiles>C=C(C)C(C)C</smiles>

protein

protein protein enzyme molecules.

Iso-octane extracted enzyme molecules.

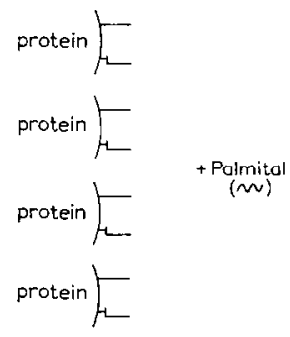

Palmital occupies its sites.

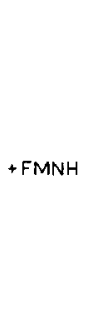

The light reaction takes place uninhibited.
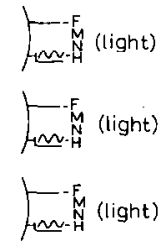<smiles>O[AsH2]1N[C@H]2C[I-]21</smiles>

after $a$
certain certain

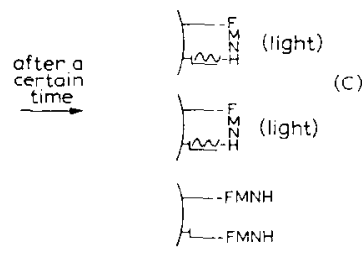

The equilibrium is established.<smiles>CCNOC1CCCC1C</smiles><smiles>C1CC2CCC(C2)N1</smiles><smiles>CC1CCCC1NC1CC1</smiles>

Fig. 2. Explanation see text. 
following may demonstrate that the experimental facts fit into this hypothetical explanation.

Is is assumed that each luciferase molecule contains one (or a few) groups to which palmital can be attached. (Since the concentration of palmital required for obtaining a maximal light reaction is extremely low, this assumption seems reasonable.) Moreover, the enzyme preparations contain an inhibitor (I). This inhibitor may prevent, at least to a considerable extent, the added FMNH from being bound to the palmital groups. The inhibitor, probably of a lipid nature, is removed by iso-octane extraction. It is assumed, furthermore, that $\mathrm{FMN}(\mathrm{H})$ can block the groups of the enzyme molecules that are to bind palmital. Such a blocking may be likewise inhibited by the inhibitor. Besides, we have to assume that the affinity of the inhibitor to the enzyme decreases if the enzyme is occupied with palmital.

In our previous article ${ }^{17}$ we assumed the presence of a site for FMNH at the enzyme, from which it could be repelled by aldehyde in excess concentration. This was suggested on the ground of a flash reaction observed in preparations of Photobacterium splendidum after addition of decanal to an enzyme preparation already containing DPNH + FMN. In view of the present experiments we assume FMNH to be bound to the protein via the aldehyde. This does not exclude the possibility that FMNH is likewise directly bound to the protein. Actually, the optimum in the curve: FMN concentration versus light reaction ( $c f$. ref. 7 ) may indicate a two-point attachment of FMNH ( $c f$. ref. 20). TOTTER AND CORMIER ${ }^{7}$ explained the optimum in the FMN concentration for the light reaction by assuming that there is competition between FMN and FMNH for a site at the luciferase molecule. However, the FMN concentration is still limiting for the DPNH-oxidase reaction in the same enzyme preparation. Therefore, the velocity of DPNH oxidation (and FMN reduction) will depend on FMN concentration. Owing to the autoxidation of FMNH the equilibrium of the reaction $\mathrm{DPNH}+\mathrm{FMN} \rightarrow \mathrm{DPN}+\mathrm{FMNH}$ is far to the right. Therefore, the ratio FMN concentration/FMNH concentration is not likely to be greatly influenced by increasing the FMN concentration above the optimal concentration for the light reaction. Consequently, it does not seem probable that the optimum for FMN concentration in the light reaction is due to competition between FMN and FMNH. A two-point attachment of FMNH to the protein may provide another explanation for the phenomenon.

Fig. 2 represents the results and assumptions discussed and suggests what may happen if palmital and FMNH are added to the enzyme, which has or has not been extracted with iso-octane.

We wish to emphasize that this scheme, for the sake of clarity, represents only extreme, idealized cases. In Fig. 2 there is no difference in light reactions of A and B. In "reality" not all sites in the unextracted enzyme will be inhibited by $\mathrm{I}$. The scheme explains, however, why the decrease of the light reaction, caused by adding FMNH first, is less conspicuous in the unextracted enzyme preparations than in the iso-octane-extracted ones. Moreover, the enzyme preparations probably contain some long-chain aldehyde already; it was assumed that the presence of palmital decreases the affinity of the inhibitor to the enzyme. We may suppose, therefore, that the percentage of the aldehyde-occupied sites inhibited by $I$ is smaller than the percentage of aldehyde-free sites inhibited by I. This may explain why the experimental results seemed to indicate that the effect of iso-octane extraction is less when 
palmital is not added than when it is added. Besides, a small part of the enzymebound aldehyde is likely to be extracted by iso-octane.

The fact that FMN and DPNH are both active in the "addition sequence effect" may be explained by assuming that both molecules are able to block the sites on the enzyme that are "intended" for the aldehyde.

The increasing effect at increasing FMN concentration and decreasing palmital concentration may be understood in terms of competition of $\mathrm{FMN}(\mathrm{H})$ and palmital for a site on the enzyme.

It may be remarked that the presented scheme should be considered as a working hypothesis. So far, it offers an explanation of the experimental results.

\title{
REFERENCES
}

1 B. L. Strehler and M. J. Cormier, Arch. Biochem. Biophys., 47 (1953) I6.

2 M. J. Cormier and B. L. Strehler, J. Am. Chem. Soc., 75 (I953) 4864.

${ }^{3}$ M. J. Cormier And J. R. Totter, Biochim. Biophys. Acta, 25 (I957) 229.

4 W. D. McElroy, J. W. Hastings, V. Sonnenfeld and J. Coulombre, J. Bacteviol., 67 (1954) 402.

${ }^{5}$ K. W. Rosenmund, Ber., 5I (I9I8) 585 .

${ }^{6}$ J. A. Smit, J. M. W. Milatz And C. SMit, Physica, 20 (1954) 39.

7 J. R. Totter and M. J. Cormier, J. Biol. Chem., 216 (I955) 80 .

8 E. Racker, J. Biol. Chem., I 77 (I949) 883.

9 J. Folch, I. Ascoli, M. Lees, J. A. Meath and F. N. Lebaron, J. Biol. Chem., I9I (I95I) 833.

$10 \mathrm{~J}$. B. Wittenberg, S. R. Korey and F. H. Swenson, J. Biol. Chem., 2 I9 (1956) 39.

11 W. D. McElroy and A. A. Green, Arch. Biochem. Biophys., 56 (I955) 240.

12 A. Nason and I. R. Lehman, $J$. Biol. Chem., 222 (I956) $5 \mathrm{II}$.

13 K. O. Donaldoson and A. Nason, Proc. Natl. Acad. Sci. U.S., 43 (1957) 364.

14 D. Deul, E. C. Slater and L. Veldstra, Biochim. Biophys. Acta, 27 (I958) I 33.

${ }^{15}$ E. R. Retpearn and A. L. Pumphrey, Biochim. Biophys. Acta, 30 (1958) 437.

${ }^{16}$ C. J. Pollard and J. G. Biert, Biochim. Biophys. Acta, 30 (I958) 437.

${ }^{17}$ W. Terpstra, Biochim. Biophys. Acta, 28 (1958) I 59.

${ }^{18}$ D. E. Green, D. Herbert and V. Subrahmanyan, $J$. Biol. Chem., i 38 (I94I) 327.

19 A. L. Lehninger, Physiol. Rev., 30 (I950) 393.

${ }^{20} \mathrm{H}$. Theorell and A. P. Nygaard, Acta Chem. Scand., 8 (1954) I649.

Biochim. Biophys. Acta, 4⿻ (1960) 55-67

\section{THE TRANSFER OF A BIOLOGICALLY ACTIVE IRRADIATION PRODUCT FROM CELL TO CELL *}

\author{
ERNEST BOREK AND ANN RYAN \\ Department of Biochemistry, College of Physicians and Surgeons, Columbia University, \\ New York, N.Y. (U.S.A.)
}

(Received October 3oth, 1959)

\section{SUMMARY}

Some product exists in a lysogenic organism after ultraviolet irradiation which can be transferred during conjugation to an unirradiated cell wherein it duplicates the effects of direct irradiation. The product is stable in the cold, unstable at $37^{\circ}$ and is unstable to illumination by visible light. The nature of the irradiated product is unknown but it is apparently not the prophage.

\footnotetext{
*A preliminary report has been published ${ }^{\mathbf{1}}$.
} 